\title{
Serum levels of retinol binding protein 4 in women with different levels of adiposity and glucose tolerance
}

\author{
Níveis séricos da proteína carreadora do retinol 4 em mulheres \\ com diferentes níveis de adiposidade e tolerância à glicose
}

Eleonora Beltrame Comucci', Ana Carolina Junqueira Vasques',

Bruno Geloneze', Antonio Ramos Calixto', José Carlos Pareja', Marcos Antonio Tambascia'

\begin{abstract}
Objective: Retinol-binding protein 4 (RBP4) is an adipokine responsible for vitamin A (retinol) transportation. Studies associated RBP4 increased levels with severity of type 2 diabetes mellitus (T2DM) and insulin resistance (IR). The study aimed to quantify RBP4 serum standards in women with a wide range of body mass index (BMI) and glucose tolerance level. Subjects and methods: Cross-sectional study was performed with 139 women divided into three groups: Group 1 (lean-control, $n=45$ ) and Group 2 (obese, $n=53$ ) with normal glucose tolerance and group 3 (obese with T2DM, $n=41$ ), called G1, G2 and G3. Were assessed clinical, biochemical, anthropometric and body composition parameters. Results: According to data analysis, we obtained in G1 higher RBP4 levels (104.8 $\pm 76.8 \mathrm{ng} / \mathrm{mL})$ when compared to $\mathrm{G} 2(87.9 \pm 38 \mathrm{ng} / \mathrm{mL})$ and G3 $(72.2 \pm 15.6 \mathrm{ng} / \mathrm{mL})$ levels. Also, were found: in $\mathrm{G} 1$ positive correlations of RBP4 with BMI $(r=0.253)$, glycated hemoglobin $(r=0.378)$ and fasting insulin $(r=0.336)$; in $G 2$ with glycated hemoglobin $(r=0.489)$; in G3 with glycated hemoglobin $(r=0.330)$, fasting glucose $(r=0.463)$, HOMA-IR ( $r=0.481)$. Conclusions: Although RBP4 have shown lower levels in diabetic and obese, a strong correlation with HOMA-IR index highlights that, in our study, there is growing IR when there is an increasing in RBP4 levels. Arq Bras Endocrinol Metab. 2014;58(7):709-14
\end{abstract}

\section{Keywords}

Obesity; metabolic syndrome; insulin resistance; women; premenopause

\section{RESUMO}

Objetivo: A proteína carreadora do retinol 4 (RBP4) é uma adipocina responsável pelo transporte de vitamina A (retinol). Estudos associam os níveis aumentados de RBP4 com a gravidade do diabetes melito tipo 2 (DM2) e resistência à insulina (RI). 0 objetivo deste estudo foi investigar como esses níveis se comportam em mulheres com ampla variação do índice de massa corporal (IMC) e tolerância à glicose. Sujeitos e métodos: Estudo transversal realizado com 139 mulheres, divididas em três grupos: Grupo 1 (controles-magras; $n=45$ ) e Grupo 2 (obesas; $n=$ 53), com tolerância normal à glicose; Grupo 3 (obesas DM2; $n=41$ ), denominados G1, G2 e G3. Foram avaliados parâmetros clínicos, bioquímicos, antropométricos e composição corporal. Resultados: De acordo com a análise dos dados, obtivemos em G1 maiores níveis de RBP4 $(104,8 \pm 76,8 \mathrm{ng} / \mathrm{mL})$ em comparação ao $\mathrm{G} 2(87,9 \pm 38 \mathrm{ng} / \mathrm{mL})$ e G3 $(72,2 \pm 15,6 \mathrm{ng} / \mathrm{mL})$. Também foram encontradas correlações positivas entre RBP4 e IMC $(r=0,253)$, hemoglobina glicada $(r=$ $0,378)$ e insulinemia de jejum $(r=0,336)$; em G2 com hemoglobina glicada $(r=0,489)$; $\mathrm{G} 3$ com hemoglobina glicada $(r=0,330)$, insulinemia de jejum $(r=0,463)$ e HOMA-IR $(r=0,481)$. Conclusões: Embora a RBP4 tenha apresentado níveis menores em pacientes diabéticas e obesas, a forte correlação com o índice HOMA-IR deixa claro que, em nosso estudo, há crescente RI quando os níveis dessa proteína também são crescentes. Arq Bras Endocrinol Metab. 2014;58(7):709-14

\section{Descritores}

Obesidade; síndrome metabólica; resistência à insulina; mulheres; pré-menopausa
Laboratory of Investigation on Metabolism and Diabetes (Limed), Department of Internal Medicine, Faculty of Medical Sciences, State University of Campinas (Unicamp), Campinas, SP, Brazil

Correspondence to:

Eleonora Beltrame Comucci Laboratório de Investigação em Metabolismo e Diabetes,

Universidade Estadual de Campinas, Rua Carlos Chagas, 420

Cidade Universitária "Zeferino Vaz" 13081-970 - Campinas, SP, Brazil eleonora@fcm.unicamp.br

Received on Oct/17/2012 Accepted on July/30/2014 DOI: 10.1590/0004-2730000002431 


\section{INTRODUCTION}

$\mathrm{T}$ he complex pathogenesis linking obesity, type 2 diabetes mellitus (T2DM), hypertension and dyslipidemia involve mechanisms ranging from increased insulin resistance (IR) through adipocytes production of pro-inflammatory and pro-oxidants factors. Adipose tissue is the largest endocrine organ of human body which regulates glucose homeostasis, steroid production, immune system action, hematopoietic and reproductive function. Despite a strong epidemiological association, overweight does not explain itself T2DM development (1-7).

Adipokines are cytokines produced and secreted by adipose tissue. Many studies have suggested a central role of this endocrine organ predominantly in routes of fat storage and insulin action. Adipokines have been suggested as good markers of metabolic syndrome and unregulated production of these cytokines may change metabolic homeostasis, insulin sensitivity, immune response and cardiovascular disease (8). Retinol binding protein 4 (RBP4) is an adipokine with recent discovery, reported by contributing to the IR and T2DM, belongs to lipocalins family and transports vitamin A (retinol) from liver to peripheral tissues. The protein encoder gene is located on chromosome $10(10 \mathrm{q} 23.33)$ near regions encoding genes linked to increased levels of fasting glucose, such as gene TCF7L2 (10q25.3) which controls CREB and Fox01 genes (9-12).

Liver is responsible for major seric output of RBP4, followed by adipose tissue which expresses $20 \%$ to $40 \%$ of liver expression. The exact physiological function of adipocyte-derived RBP4 is unclear. A recent study has shown that vitamin $\mathrm{A}$ and its metabolites regulate adipogenesis. RBP4 production is elevated in animal models with severe IR (GLUT4 knockout only in adipose tissue), resulting in up-regulation of RBP4 expression and hyperglycemia by the interference of insulin signaling (13-15).

RBP4 serum levels are elevated in subjects with impaired glucose tolerance, T2DM and inversely correlated with insulin sensitivity in non-diabetic subjects with familial history of T2DM. RBP4 levels correlate with degree of IR in those subjects, and this relation is independent of obesity (16-25). In addition to lower insulin sensitivity, a negative effect on secretion of $\beta$-cells caused by RBP4 is suggested. On the other hand, there is a variety of recent studies that did not find in RBP4 an accurate biomarker of IR and MS in diabetic or normal subjects (26-28).
The study aimed to quantify RBP4 serum standards in women with a wide range of body mass index (BMI) and glucose tolerance level.

\section{SUBJECTS AND METHODS}

\section{Study design}

A cross-sectional study was conducted at the Laboratory of Investigation on Metabolism and Diabetes (LIMED) - State University of Campinas - Brazil.

\section{Sample}

A total of 139 women were assessed and divided into three groups: Group 1 (Lean-control, $\mathrm{n}=45$ ), Group 2 (obese, $\mathrm{n}=53$ ), both with normal glucose tolerance, and Group 3 (obese with T2DM, n = 41), called Gl, G2 and G3. T2DM was diagnosed according to the American Diabetes Association criteria.

The inclusion criteria were age over 20 years old, premenopause and negative islet autoimmunity. The exclusion criteria were use of incretin mimetics, dipeptidyl peptidase- 4 inhibitors or insulin; significant kidney or liver dysfunction; recent neoplasia $(<5$ years); and use of oral or injectable corticosteroids for more than 14 consecutive days in the last 3 months.

This study was approved by Ethics Committee of Faculty of Medical Sciences of State University of Campinas, Brazil. All participants provided written informed consent before participation.

\section{Anthropometrical and body composition assessment}

The subjects were measured by same examiner, wearing light clothes and no shoes. Height was determined using a stadiometer fixed to the wall and weight was measured on an electronic digital scale positioned on a flat surface. BMI was calculated. Sagittal abdominal diameter (SAD) was measured nearest to $0.1 \mathrm{~cm}$ after a normal expiration while subjects were in supine position with their knees slightly bent on a firm examination table. Measurement was taken at umbilicus level using the Holtain-Kahn Abdominal Caliper ${ }^{\mathrm{TM}}$, a portable sliding-beam caliper. Waist circumference was measured at standing position by a measuring tape at the umbilicus level after a normal expiration without clothing present in measurement area. Amounts of body fat and fat-free mass were determined using a bioimpedance analyzer (model BIA 310) according to manufacturer's protocol (31). 


\section{Assays}

Plasma glucose levels were promptly measured in fasting state using a glucose analyzer (YSI 2700; YSI Life Sciences, Yellow Spring, OH, USA) with a CV of $2 \%$. Glycated hemoglobin was measured with high-performance liquid chromatography (HPLC). Plasma insulin was analyzed using an automated two-site chemiluminescent immunometric assay (Immulite 1000 System; Siemens Health Diagnostics, USA). Intra-assay and inter-assay variation coefficients were $5.2-6.4 \%$ and $5.9-8.0 \%$. Total cholesterol, HDL cholesterol, triglycerides, were measured by enzymatic colorimetric method. LDL cholesterol levels were calculated using Friedewald method. RBP4 was measured in duplicate by ELISA (Phoenix Pharmaceuticals, Inc.). For statistical analysis we considered the mean of two values obtained. Variation coefficients intra and inter-assay were $4.5 \%$ and $7 \%$, respectively.

\section{Insulin resistance assessment}

Insulin resistance was measured using HOMA-IR (Homeostasis Model Assessment - Insulin Resistance) ( $\mathrm{Fi}$ gure 1):

$$
\text { HOMA-IR }=\frac{\text { Fasting insulin }(\mathrm{mU} / \mathrm{L}) \times \text { Fasting glucose }(\mathrm{mmol} / \mathrm{L})}{22,5}
$$

Figure 1. HOMA-IR formula.

\section{Statistical analysis}

Statistical analysis were performed using SPSS 20.0 (Chicago, IL, USA). In descriptive analysis, continuous variables were described using measures of central tendency and dispersion. Kolmogorov-Smirnov test was used to assess normality of distribution of variables. The comparison among three study groups (G1, G2 and G3) was performed applying Kruskal Wallis test. In situations where there was a statistically significant difference was used post-hoc Bonferroni test to identify which groups differed. Correlations among study variable RBP4 with other anthropometric parameters, body composition and metabolism were analyzed by Spearman correlation test. The level of significance as a basis for decision was less than $5 \%(\mathrm{p}<0.05)$.

\section{RESULTS}

Although all the women assessed were in menacme period, G1 was slightly younger than G3 ( $p<0.001)$. Interestingly, even with the same grade of obesity
(BMI and body fat percentage), patients within G3 had larger waist circumferences and larger SAD than those within G2 ( $\mathrm{p}<0.001)$, indicating increased central fat distribution. As expected, G3 presented elevated levels of glycated hemoglobin and fasting glucose compared to G1 and G2. Fasting insulin was similar among G2 and G3, and augmented compared to Gl $(\mathrm{p}<0.001)$. HOMA-IR presented increased levels across three study groups, G1 $<$ G2 $<$ G3 $(\mathrm{p}<$ $0.001)$. Levels of total cholesterol and LDL-cholesterol, did not differ among groups, however, levels of HDL-cholesterol were augmented and levels of triglycerides were diminished in G1 and G2 compared to G3 ( $<<0.05$ ) (Table 1). In G3, RBP4 levels were lower when compared to Gl $(\mathrm{p}<0.05)$ and similar to G2 (Figure 2).

In Gl, serum RBP4 correlated positively with BMI $(\mathrm{r}=0.253)$, glycated hemoglobin $(\mathrm{r}=0.378)$ and fasting insulin $(\mathrm{r}=0.336)(\mathrm{p}<0.05)$; in G2, serum RBP4 correlated positively with glycated hemoglobin $(\mathrm{r}=0.489 ; \mathrm{p}<0.01)$ and in G3 serum RBP4 correlated positively with glycated hemoglobin $(\mathrm{r}=0.330$; $\mathrm{p}<0.05)$, fasting glucose $(\mathrm{r}=0.463)$, HOMA-IR $(\mathrm{r}=$ $0.481),(\mathrm{p}<0.01)$ (Figure $3 \mathrm{C})$.

\section{DISCUSSION}

The main finds of present study were: 1) Serum RBP4 levels were diminished in obese patients with T2DM (G3), compared to patients without T2DM (G2) and controls (Gl). The last two groups had statistically equal results; 2) BMI was positively correlated with RBP4 levels in G1, although anthropometric indicators of central fat accumulation (waist circumference and SAD) did not correlate with RBP4; 3 ) Glycated hemoglobin was consistently positive correlated with RBP4 levels in all studied groups; 4) RBP4 levels correlated with HOMA-IR in G3, demonstrating that this adipokine figures as a marker of IR in patients with obesity and T2DM.

1) Serum RBP4 levels were diminished in obese patients with T2DM (G3) compared to patients without T2DM (G2), and without T2DM and obesity (G1).

There seems to be a number of factors interfering with correlations and that should be considered when interpreting results. Furthermore, genetic differences in profile of studied populations, relationships among gender and age, have an important role in interpretation and comparison of data obtained (21). 
Table 1. Clinical and metabolic characteristics of the three groups of patients studied

\begin{tabular}{|c|c|c|c|c|c|c|c|c|c|c|}
\hline \multirow[b]{3}{*}{ Age (years) } & \multicolumn{3}{|c|}{$\begin{array}{c}\text { G1 } \\
\text { Lean controls } \\
(n=45)\end{array}$} & \multirow{2}{*}{\multicolumn{3}{|c|}{$\begin{array}{c}\begin{array}{c}\text { G2 } \\
\text { Obese } \\
(n=53)\end{array} \\
\text { Mean } \pm \text { SD }\end{array}$}} & \multicolumn{3}{|c|}{$\begin{array}{c}\text { G3 } \\
\text { T2DM obese } \\
(n=41)\end{array}$} & \multirow{3}{*}{$\begin{array}{r}\boldsymbol{p} \text {-value } \\
0.003\end{array}$} \\
\hline & \multirow[b]{2}{*}{37} & \multirow[b]{2}{*}{ \pm} & \multirow[b]{2}{*}{7.5} & & & & \multirow[b]{2}{*}{$43_{b}$} & \multirow[b]{2}{*}{ \pm} & \multirow[b]{2}{*}{7.0} & \\
\hline & & & & $39_{\text {a.b }}$ & \pm & 7.0 & & & & \\
\hline $\mathrm{BMI}\left(\mathrm{kg} / \mathrm{m}^{2}\right)$ & $24.3_{a}$ & \pm & 2.4 & $35.6_{b}$ & \pm & 4.6 & $37.0_{b}$ & \pm & 4.5 & 0.001 \\
\hline Waist circumference $(\mathrm{cm})$ & $85.9_{a}$ & \pm & 7.4 & $107.8_{b}$ & \pm & 10.2 & $115.9_{c}$ & \pm & 10.0 & 0.001 \\
\hline $\mathrm{SAD}(\mathrm{cm})$ & $18.4_{a}$ & \pm & 1.8 & $24.0_{b}$ & \pm & 2.9 & $26.0_{c}$ & \pm & 2.9 & 0.001 \\
\hline Body fat (kg) & $31.8_{a}$ & \pm & 3.7 & $40.7_{b}$ & \pm & 3.9 & $40.7_{b}$ & \pm & 3.5 & 0.001 \\
\hline [RBP4] (ng/mL) & $104.8_{\mathrm{a}}$ & \pm & 76.8 & $87.9_{a, b}$ & \pm & 38.0 & $72.2_{b}$ & \pm & 15.6 & 0.178 \\
\hline Glycated hemoglobin (\%) & $5.2_{a}$ & \pm & 0.88 & $5.5_{a}$ & \pm & 0.91 & $7.6_{b}$ & \pm & 2.07 & 0.001 \\
\hline Fasting insulin (mU/l) & 6.9 & \pm & 4.2 & $12.7_{b}$ & \pm & 7.5 & $14.6_{b}$ & \pm & 11.3 & 0.001 \\
\hline Fasting plasma glucose (mg/dL) & $78.7_{\mathrm{a}}$ & \pm & 8.6 & $82.2_{a}$ & \pm & 10.9 & $147.7_{b}$ & \pm & 66.9 & 0.001 \\
\hline HOMA-IR & $1.3_{\mathrm{a}}$ & \pm & 0.8 & $2.5 b$ & \pm & 1.5 & $5.0_{c}$ & \pm & 3.6 & 0.001 \\
\hline Total cholesterol (mg/dL) & $183_{\mathrm{a}}$ & \pm & 33.6 & $191_{\mathrm{a}}$ & \pm & 41.7 & $183_{\mathrm{a}}$ & \pm & 38.5 & 0.595 \\
\hline HDL cholesterol (mg/dL) & $54_{a}$ & \pm & 11.0 & $50_{a}$ & \pm & 12.7 & $39_{b}$ & \pm & 9.2 & 0.001 \\
\hline LDL cholesterol (mg/dL) & $110_{a}$ & \pm & 31.1 & $121_{a}$ & \pm & 34.7 & 108 & \pm & 33.3 & 0.220 \\
\hline Triglycerides (mg/dL) & $94_{a}$ & \pm & 56.6 & $118 \mathrm{a}$ & \pm & 71.0 & $193_{b}$ & \pm & 191.4 & 0.001 \\
\hline
\end{tabular}

Note: values in the same row and subtable who do not share the same subscript are significantly different at $\mathrm{p}<0.05$ (Bonferroni test).

BMI: body mass index; SAD: sagittal abdominal diameter; RBP4: retinol binding protein 4; HOMA-IR: Homeostasis Model Assessment - Insulin Resistance among.
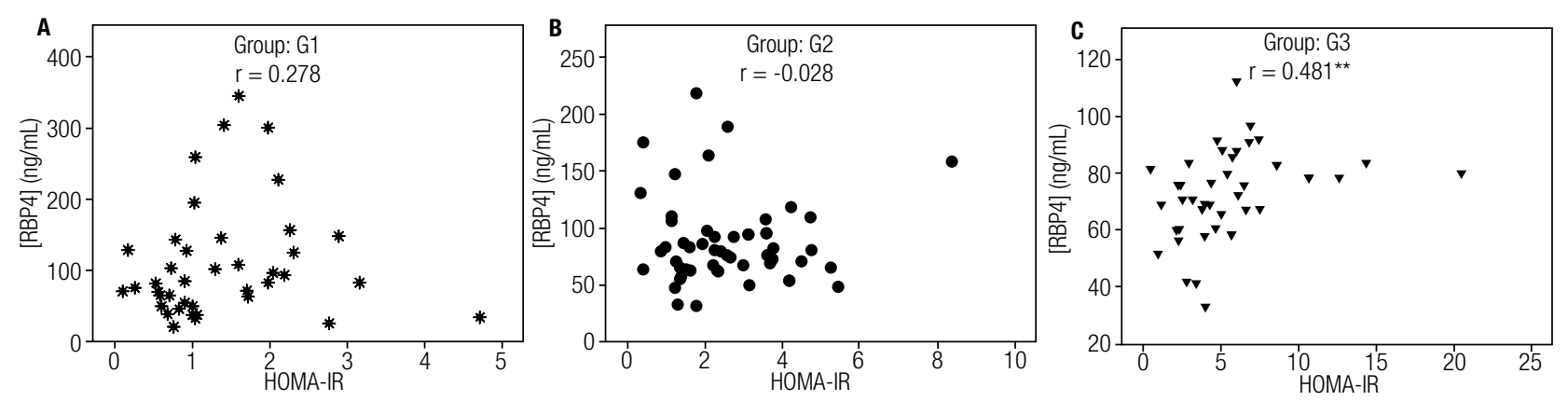

Figure 2. Correlation among serum RBP4 levels with HOMA-IR index in three HOMA-IR groups of patients studied. (A) lean controls; (B) obese; (C) T2DM obese.

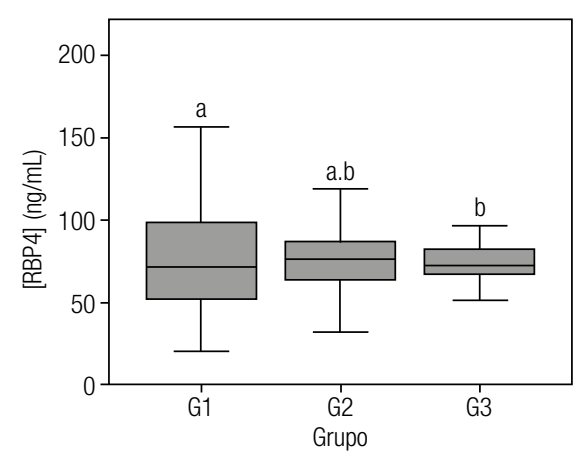

Figure 3. Levels of RBP4 in three groups. a and b represent groups that differed statistically at $p<0.05$ (Bonferroni test).

* Correlation is significant at $p<0.05$ (two-tailed); ${ }^{* *}$ Correlation is significant at $p<0.01$ (two-tailed).
G1 and G3 differed significantly in age, which probably reflects in levels of RBP4. There was a positive correlation $(\mathrm{p}<0.05)$ among age and levels of RBP4 in G2. No gender difference was analyzed since the study included only women in menacme period.

2) Although BMI was positively correlated with RBP4 levels in Gl, anthropometric indicators of central fat accumulation (waist circumference and SAD) did not correlate with RBP4.

Evaluating correlation among RBP4 $\mathrm{x}$ BMI and RBP4 x \% Body fat, is noted that body fat amount appears to be more correlated with levels of this adipokine than BMI itself. 
3) Glycated hemoglobin was consistently correlated with RBP4 levels in all studied groups.

Our findings show that glycated hemoglobin levels were significantly correlated in all groups with levels of RBP4. While when we evaluated fasting glucose there was no such trend in G1 and G2, groups without T2DM.

In G3, whose fasting glucose is greater than in other groups, there was a strong positive correlation following the tendency of increased glycated hemoglobin levels. This finding, in particular, confirms existing literature (7), higher was the level of RBP4 in obese diabetic more correlated with levels of fasting glucose and glycated hemoglobin, perhaps because RBP4 gene encoder is located very near genes linked to obesity and T2DM.

4) RBP4 levels correlated with HOMA-IR in G3, demonstrating this adipokine figures as a marker of IR in patients with obesity and T2DM.

The RBP4 is an adipokine consistently associated with IR in animal models (knockout only for GLUT4 receptor in adipose tissue) and was also considered a promising adipokine in humans, possibly linking adiposity, IR, T2DM and certain components of the metabolic syndrome (11,31).

Retinol binding protein 4 seems to be involved in early phases of IR development and other metabolic syndrome components. Therefore, longitudinal studies are needed to investigate how change will occur in RBP4 levels especially in children and adolescents predisposed to these conditions.

The study of RBP4 must be extensive, due to various sources and polymorphisms in genes encoding this protein and genes encoding one of its receptors.

In this study we found a positive correlation among RBP4 levels and some biochemical parameters. However, in several clinical studies, associations and/or causality of changes in the expression of RBP4 were not demonstrated (21).

\section{Limitations of study}

Methodological differences in sample collection and determination of RBP4 levels should be considered. Studies showed there is a variation in protein quantification according to used methods (21).

Other interfering factors, such as levels of retinol, iron and even renal function appear to be important and should be investigated in future studies (18).
Deeper studies, using other research methods with human adipocytes, are necessary to reveal how secretion and regulation of RBP4 expression works and its self-paracrine effect.

Differences in results of this study regarding others can also be caused by different methods of RBP4 quantification.

\section{CONCLUSIONS}

In our study, unexpectedly, the levels of RBP4 were reduced in patients with both obesity and T2DM compared to patients without obesity and T2DM. On the other hand, consistently thorough the three groups, RPB-4 was positively and strongly correlated with glycated hemoglobin and with IR in the G3.

This apparent discrepancy, also demonstrated by other studies, may be explained by the interference of other factors (assay technique, genetic variations, levels of retinol, iron and even renal function), or metabolic control degree.

Acknowledgements: we thank Fundação de Amparo à Pesquisa do Estado de São Paulo (Fapesp) and Coordenação de Aperfeiçoamento de Pessoal de Nivel Superior (Capes) for their financial support.

Disclosure: no potential conflict of interest relevant to this article was reported.

\section{REFERENCES}

1. Kahn SE, Prigeon RL, Schwartz RS, Fujimoto WY, Knopp RH, Brunzell JD, et al. Obesity, body fat distribution, insulin sensitivity and Islet beta-cell function as explanations for metabolic diversity. $J$ Nutr. 2001;131(2):354S-60S.

2. Kahn SE, Hull RL, Utzschneider KM. Mechanisms linking obesity to insulin resistance and type 2 diabetes. Nature. 2006;444(7121):840-6.

3. Kershaw EE, Flier JS. Adipose tissue as an endocrine organ. J Clin Endocrinol Metab. 2004;89(6):2548-56.

4. Després JP. Body fat distribution and risk of cardiovascular disease: an update. Circulation. 2012;126(10):1301-13.

5. Vague J. Les Obésités: etudes biométriques. Press Medical. 1947;(30):339.

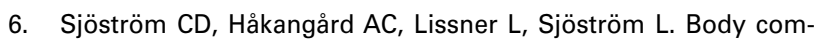
partment and subcutaneous adipose tissue distribution--risk factor patterns in obese subjects. Obes Res. 1995;3(1):9-22.

7. Ravussin E, Smith SR. Increased fat intake, impaired fat oxidation, and failure of fat cell proliferation result in ectopic fat storage, insulin resistance, and type 2 diabetes mellitus. Ann NY Acad Sci. 2002;967:363-78.

8. Trayhurn P, Wood IS. Adipokines: inflammation and the pleiotropic role of white adipose tissue. Br J Nutr. 2004;92(3):347-55.

9. Berg $\mathrm{AH}$, Scherer PE. Adipose tissue, inflammation, and cardiovascular disease. Circ Res. 2005;96(9):939-49. 
10. Fantuzzi G. Cytokines: pulling the body together as a whole. ScientificWorldJournal. 2011;11:2506-8.

11. Colantuoni V, Romano V, Bensi G, Santoro C, Costanzo F, Raugei $\mathrm{G}$, et al. Cloning and sequencing of a full length cDNA coding for human retinol-binding protein. Nucleic Acids Res. 1983;11(22):7769-76.

12. Oh KJ, Park J, Kim SS, Oh H, Choi CS, Koo SH. TCF7L2 modulates glucose homeostasis by regulating CREB- and FoxO1-dependent transcriptional pathway in the liver. PLoS Genet. 2012;8(9):e1002986.

13. Gnudi L, Shepherd PR, Kahn BB. Over-expression of GLUT4 selectively in adipose tissue in transgenic mice: implications for nutrient partitioning. Proc Nutr Soc. 1996;55(1B):191-9.

14. Villarroya F, Iglesias $R$, Giralt $M$. Retinoids and retinoid receptors in the control of energy balance: novel pharmacological strategies in obesity and diabetes. Curr Med Chem. 2004;11:795-805.

15. Ziouzenkova O, Orasanu G, Sharlach M, Akiyama TE, Berger JP, Viereck $J$, et al. Retinaldehyde represses adipogenesis and diet-induced obesity. Nat Med. 2007;13(6):695-702.

16. Yang Q, Graham TE, Mody N, Preitner F, Peroni OD, Zabolotny JM, et al. Serum retinol binding protein 4 contributes to insulin resistance in obesity and type 2 diabetes. Nature. 2005;436(7049):356-62.

17. Basualdo $C G$, Wein EE, BasuTK. Vitamin $A$ (retinol) status of first nation adults with non-insulin-dependent diabetes mellitus. J Am Coll Nutr. 1997;16(1):39-45.

18. Abahusain MA, Wright J, Dickerson JW, de Vol EB. Retinol, alpha-tocopherol and carotenoids in diabetes. Eur J Clin Nutr. 1999;53(8):630-5.

19. Klöting N, Fasshauer M, Dietrich A, Kovacs P, Schön MR, Kern M, et al. Insulin-sensitive obesity. Am J Physiol Endocrinol Metab. 2010;299(3):E506-15.

20. Graham TE, Yang $Q$, Blüher M, Hammarstedt A, Ciaraldi TP, Henry $\mathrm{RR}$, et al. Retinol-binding protein 4 and insulin resistance in lean, obese, and diabetic subjects. N Engl J Med. 2006;354(24):2552-63.

21. Kotnik P, Fischer-Posovszky P, Wabitsch M. RBP4: a controversial adipokine. Eur J Endocrinol. 2011;165(5):703-11.
22. Munkhtulga L, Nagashima S, Nakayama K, Utsumi N, Yanagisawa $Y$, Gotoh T, et al. Regulatory SNP in the RBP4 gene modified the expression in adipocytes and associated with BMI. Obesity (Silver Spring). 2010;18(5):1006-14.

23. Kovacs P, Geyer M, Berndt J, Klöting N, Graham TE, Böttcher $Y$, et al. Effects of genetic variation in the human retinol binding protein-4 gene (RBP4) on insulin resistance and fat depot-specific mRNA expression. Diabetes. 2007;56(12):3095-100.

24. Munkhtulga L, Nakayama K, Utsumi N, Yanagisawa $Y$, Gotoh T, Omi T, et al. Identification of a regulatory SNP in the retinol binding protein 4 gene associated with type 2 diabetes in Mongolia. Hum Genet. 2007;120(6):879-88.

25. Craig RL, Chu WS, Elbein SC. Retinol binding protein 4 as a candidate gene for type 2 diabetes and prediabetic intermediate traits. Mol Genet Metab. 2007;90(3):338-44.

26. Santoro N, Perrone L, Cirillo G, Brienza C, Grandone A, Cresta N, et al. Variations of retinol binding protein 4 levels are not associated with changes in insulin resistance during puberty. J Endocrinol lnvest. 2009;32(5):411-4.

27. Ulgen $F$, Herder $C$, Kühn MC, Willenberg HS, Schott M, Scherbaum WA, et al. Association of serum levels of retinol-binding protein 4 with male sex but not with insulin resistance in obese patients. Arch Physiol Biochem. 2010;116(2):57-62.

28. Henze A, Frey SK, Raila J, Tepel M, Scholze A, Pfeiffer AF, et al. Evidence that kidney function but not type 2 diabetes determines retinol-binding protein 4 serum levels. Diabetes. 2008;57(12):3323-6.

29. Lukaski HC, Bolonchuk WW, Hall CB, Siders WA. Validation of tetrapolar bioelectrical impedance method to assess human body composition. J Appl Physiol (1985). 1986;60(4):1327-32.

30. Matthews DR, Hosker JP, Rudenski AS, Naylor BA, Treacher DF, Turner RC. Homeostasis model assessment: insulin resistance and beta-cell function from fasting plasma glucose and insulin concentrations in man. Diabetologia. 1985;28(7):412-9.

31. Gregoire FM. Adipocyte differentiation: from fibroblast to endocrine cell. Exp Biol Med (Maywood). 2001;226(11):997-1002. 